\title{
İlkokulda Temel Fen Bilimleri Dersine Yönelik Akademisyen Görüşleri
}

\section{Sümeyye Aydın Gürler ${ }^{1}$}

\section{Oktay Baykara ${ }^{2}$}

\author{
Type/Tür: \\ Research/Araştırma \\ Received/Geliş Tarihi: \\ April 2/2 Nisan 2020 \\ Accepted/Kabul Tarihi: \\ December 7/7 Aralık 2020 \\ Page numbers/Sayfa No: 225-245 \\ Corresponding \\ Author/İletişimden Sorumlu \\ Yazar: s.aydingurler@gmail.com
}

\section{$\checkmark$ iThenticate}

This paper was checked for plagiarism using iThenticate during the preview process and before publication. / Bu çalışma ön inceleme sürecinde ve yayımlanmadan önce iThenticate yazılımı ile taranmıştır.

Copyright $\odot 2017$ by

Cumhuriyet University, Faculty of Education. All rights reserved.

\section{Öz}

Nitelikli öğretmen yetiştirebilmek için öğretmen yetiştiren kurumların lisans müfredatlarında çağın gereklerine uygun şekilde düzenlemeler yapılmalıdır. Bu amaçla 2018-2019 eğitim öğretim yılından itibaren uygulanmak üzere 25 lisans programının ders ve içeriklerinde düzenleme yapılmıştır. Bu yeni program, 2018-2019 öğretim yılında sadece lisans 1. sınıf öğrencilerine uygulanmıştır. Sınıf öğretmenliği alanı farklı içeriklere sahip olmasından dolayı en çok değişikliğe uğrayan öğretmenlik alanlarının başında gelmektedir. Yeni sınıf öğretmenliği lisans programındaki tüm derslerin, özellikle de fen derslerinin içeriğindeki değişiklikler programın en dikkat çekici yönüdür. Değişen yeni sınıf öğretmenliği lisans programında Genel Fizik, Genel Kimya ve Genel Biyoloji gibi alan dersleri kaldırılmıştır. Bu bağlamda bu çalışmada, eski programdaki alan derslerinin tüm konularını içeren ve yeni programda sadece bir dönemde verilecek olan İlkokulda Temel Fen Bilimleri dersi hakkında akademisyenlerin görüş ve değerlendirilmesinin ortaya konulması amaçlanmıştır. Bu çalışma nitel bir araştırma olup veriler yarı yapılandırılmış görüşme formu ile elde edilmiştir. Ölçüt örnekleme yöntemiyle de çalışmanın katılımcıları belirlenmiştir. Çalışma, 2018-2019 eğitim öğretim yılı bahar döneminde Frrat ve İnönü Üniversitelerinde görev yapan 10 öğretim üyesi ile yürütülmüştür. Veriler içerik analizi yöntemi ile analiz edilmiştir. Elde edilen sonuçlara göre, akademisyenler genel olarak İlkokulda Temel Fen Bilimleri dersinin içeriğinin ve süresinin yetersiz olduğunu ve bu içerikle fen alanında donanımlı öğretmenler yetişmeyeceğini ifade etmişlerdir.

Anahtar Kelimeler: Akademisyen görüşü, fen bilimleri, ilkokul, lisans programı, sinuf öğretmeni.

\section{Suggested APA Citation/Önerilen APA Atıf Biçimi:}

Aydın Gürler, S., \& Baykara, O. (2021). İlkokulda temel fen bilimleri dersine yönelik akademisyen görüşleri. Cumhuriyet International Journal of Education, 10(1), 225-245. http://dx.doi.org/10.30703/cije.713215

\footnotetext{
1 Dr. Öğr. Üyesi, Gaziantep Üniversitesi, Matematik ve Fen Bilimleri Eğitimi Bölümü, Gaziantep/Türkiye Assist. Prof. Dr., Gaziantep University, Department of Mathematics and Science Education, Gaziantep/Turkey e-mail: s.aydingurler@gmail.com ORCID ID: orcid.org/0000-0003-2651-4395

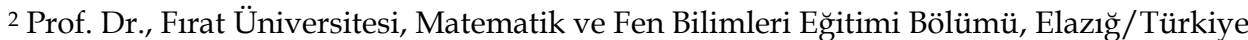
Prof. Dr., Firat University, Department of Mathematics and Science Education, Elazı $\breve{g} /$ Turkey e-mail: obaykara@gmail.com ORCID ID: orcid.org/0000-0003-4429-0401
} 


\title{
The Opinions of Academicians on Elementary Science Course in Primary School
}

\begin{abstract}
In order to train qualified teachers, arrangements should be made in the undergraduate curriculum of teacher training institutions in accordance with the requirements of the recent times. For this purpose, the courses and content of 25 undergraduate programs have been arranged to be implemented as of 2018-2019 academic year. This new program was applied only on 1st-year undergraduate students during the 2018-2019 academic year. Primary school teaching is among primary areas of teaching that underwent the most of revisions due to its complex structure. In the new primary school teaching undergraduate program, the changes in the content of all courses, particularly of science courses are the most striking aspect of the program. The field courses such as General Physics, General Chemistry and General Biology were removed in the new primary school teaching undergraduate program. In this content, the aim of current study is to determine the opinions and evaluation of academicians about the Elementary Science Course in Primary School that includes all subjects of field courses in former program and being taught in only one term in the new program. This study is a qualitative research and data was obtained with a semi-structured interview form. The participants who attended the study were determined by criterion sampling method. The study was carried out with ten academic staff working in Firat University and Inonu University in the spring semester of 2018-2019. The content analysis method was used for data analysis. According to the results, academicians generally stated that they found the content and duration of the Elementary Science Course in Primary School insufficient. Finally, the participants have also stated that teachers who are equipped in the field of science will not be raised with this content.
\end{abstract}

Keywords: Academician opinion, primary school, primary school teacher, science, undergraduate program.

\section{Giris}

Bilginin çok çabuk değiştiği günümüzde eğitimin ve süreçlerinin de değişime uğraması kaçınılmazdır. Sürecin bir parçası olan öğrenci ve öğretmenlerin yeterlilikleri de büyük değişime uğramıştır. Öğrenci bilgiyi alan, ezberleyen ve aktaran rolünden çıkıp; yaratıcı düşünen, öğrendiği yeni bilgiyi ön bilgileri üzerine inşa edebilen, analiz ve sentez yapabilen bir role bürünmüştür. Öğrenci profilindeki bu değişim öğretmen profilinin de değişmesine neden olmuştur. Öğretmen ise sadece bilgiyi aktaran değil, yol gösteren yani rehber konumuna bürünmüştür (Yurdakal, 2018). Eğitim sisteminin başarılı olarak yürütülebilmesi için sistemde önemli bir role sahip öğretmenlerin de nitelik ve nicelik olarak donanımlı olması gerekmektedir (Kavcar, 1982). Çünkü nitelikli öğretmen demek yetiştirilecek insan gücünün de nitelikli olması demektir (Çoban, 1996). Bilgi çağında öğretmenlerin rakipleri meslektaşları değil, internet siteleridir. Öğretmenlerin öğrencilerini bu dijital güçlerden daha fazla etkilemesi için yeni bir öğrenci profiline, dolayısıyla da yeni bir öğretmen yetiştirme sistemine ihtiyaç vardır (Özcan, 2013). Bu yeterliliğe sahip öğretmen yetiştirmek için de öğretmen yetiştirme politikalarında önemli değişiklikler yapılması kaçınılmazdır (Yüksel, 2015). Ülkemizde öğretmen yetiştirme anlayışında ve öğretmen yetiştirme programinda Tanzimat'tan bu yana birçok değişiklik yapılmıştır. Özellikle Cumhuriyet döneminde nitelik ve nicelik bakımından donanımlı öğretmenlerin yetiştirilmesine büyük önem verilmiştir (Çoban, 2011). 1923-1981 yıllarında ise ilkokula öğretmen yetiştirmede İki Yıllık Eğitim Enstitüleri, Köy Enstitüleri ve İlköğretmen Okulları; ortaokula öğretmen yetiştirmede Üç Yıllık Eğitim 
Enstitüleri; liselere öğretmen yetiştirmede ise Üniversiteler ve Yüksek Öğretmen Okulları önemli role sahiptir. Kısacası bu dönemde (1923-1981) öğretmen yetiştirme işlevi bir taraftan üniversiteler tarafından bir taraftan da Milli Eğitim Bakanlığı'na bağl1 yükseköğretim kurumlarınca yürütülmekteydi (Kavak, Aydın ve Akbaba-Altun, 2007). 1982 yılında öğretmen yetiştirme işlevinin üniversitelere devredilmesiyle, 1997, 2006 ve 2009 yıllarında öğretmen yetiştirme lisans programlarında yeniden düzenlemelere gidilmiştir. Bu bağlamda yapılan son değişiklik ise 2018 yılında yapılmıştır. Bu yılda yapılan değişiklikle eğitim fakültelerinin bölüm ve anabilim dalları yeniden yapılandırılmış ve öğretmen yetiştirme lisans programları güncellenmiştir. Yeni lisans programları ile eğitim fakültelerinin ders saatleri ve ders sayıları azaltılmıştır. Ayrıca yeni lisans programlarında (2018), uluslararası eğitim normlarına uymak adına AKTS yönünden fakülteler arasında standartlık sağlanmış ve seçmeli derslere \%25 oranında yer verilerek bu derslerin sayısı artırılmıştır. Böylece Avrupa Yükseköğretim Alanı yaratmayı amaçlayan ve bir reform süreci olarak da bilinen Bologna sürecine uyum sağlanmak istenmiştir (Yurdakal, 2018). Yeni program 2018-2019 öğretim yılında sadece lisans 1. sınıf öğrencilerine uygulanmıştır. Diğer sınıflar ise eğitimlerine başladıkları programla devam etmektedirler (Kılıç Özmen, 2019). Sınıf öğretmenliği alanı farklı içeriklere sahip olmasından dolayı en çok değişikliğe uğrayan öğretmenlik alanlarının başında gelmektedir (Çoban, 2011). Eski sınıf öğretmenliği lisans programının (2006) en çok dikkat çeken yönü derslerin ağırlıklı olarak bilişsel alana yönelik olması ve Milli Eğitim Bakanlığı (MEB) ve Yüksek Öğretim Kurumu (YÖK) arasında görülen uyumsuzluktur. Ayrıca 152 kredilik sınıf öğretmenliği lisans programının sadece 21 kredisi öğretmenlik meslek bilgisi dersleriyle ilgilidir (Atanur Başkan, Aydın ve Madden, 2006). Kısacası bu programda alan ve alan eğitimi derslerinin yoğunlukta olduğu görülmektedir. Yeni sinıf öğretmenliği lisans programında (2018) ise programda yer alan derslerin \%46'sını alan eğitimi dersleri, \%35'ini öğretmenlik meslek bilgisi dersleri, \%19'unu ise genel kültür dersleri oluşturmaktadır (YÖK, 2018). Hallam (2009)'a göre sinıf öğretmeni adaylarının almaya en çok ihtiyaç duyduğu dersler alan eğitimi ve öğretmenlik meslek bilgisi gibi derslerdir. 2018 yılında güncellenen lisans programları da bu amaca yönelik güncellenmiştir. Ayrıca yeni sınıf öğretmenliği lisans programındaki tüm derslerin, özellikle de fen derslerinin içeriğindeki değişiklikler programın en dikkat çekici yönüdür. Eski (2006) ve yeni (2018) sınıf öğretmenliği lisans programlarının içeriğinin fen dersleri açısından karşılaştırılması Tablo 1'de verilmiştir.

Tablo 1

Eski ve Yeni Sınıf Öğretmenliği Lisans Programlarının İçeriğ̈inin Fen Dersleri Açısından Karşılaştırılması

\begin{tabular}{|c|c|c|}
\hline Yarıyıllar & 2006 Programi & 2018 Programı \\
\hline I. Yarıyıl & Genel Biyoloii & - \\
\hline II. Yarıyıl & Genel Kimya & İlkokulda Temel Fen Bilimleri \\
\hline III. Yarıyıl & $\begin{array}{l}\text { Genel Fizik } \\
\text { Fen ve Teknoloji Lab. Uygulamaları I }\end{array}$ & Fen Bilimleri Laboratuvar Uygulamaları \\
\hline IV. Yarıyıl & Fen ve Teknoloji Lab. Uygulamaları II & $-\quad . . \quad 2$ \\
\hline V. Yarıyıl & Fen ve Teknoloji Öğretimi I & Fen Öğretimi \\
\hline VI. Yariyıl & Fen ve Teknoloji Öğretimi II & - \\
\hline
\end{tabular}


Tablo 1'e göre eski sınıf öğretmenliği lisans programına (2006) bakıldığında öğretmen adayları birinci yarıyılda "Genel Biyoloji”, ikinci yarıyılda "Genel Kimya”, üçüncü yarıyılda "Genel Fizik" ve "Fen ve Teknoloji Laboratuvar Uygulamaları I", dördüncü yarıyılda "Fen ve Teknoloji Laboratuvar Uygulamaları II", beşinci yarıyılda "Fen ve Teknoloji Öğretimi I" ve altıncı yarıyılda "Fen ve Teknoloji Öğretimi II" derslerini almaktaydılar (YÖK, 2006). 2018 programına bakıldığında ise alan dersleri (Genel Biyoloji, Genel Kimya, Genel Fizik) kaldırılmış ve ikinci yarıyılda "İlkokulda Temel Fen Bilimleri" (İTFB) adı altında alan eğitimine ağırlık veren ders getirilmiştir. Ayrica 2006 programinda laboratuvar dersi "Fen ve Teknoloji Lab. Uygulamaları I" ve "Fen ve Teknoloji Lab. Uygulamaları II" şeklinde iki dönemde verilirken; 2018 programında "Fen Bilimleri Laboratuvar Uygulamaları" adı altında tek bir dönemde verilmeye başlanmıştır. Benzer şekilde 2006 programında Fen ve Teknoloji Öğretimi dersi "Fen ve Teknoloji Öğretimi I" ve "Fen ve Teknoloji Öğretimi II" şeklinde iki dönemde verilirken; 2018 programında "Fen Öğretimi" adı altında tek bir dönemde verilmeye başlanmıştır (YÖK, 2018).

2018-2019 eğitim öğretim yılından itibaren uygulamaya konulan dolayısıyla daha yeni olan lisans programlarının içeriklerinin bölüm ve dersler bağlamında incelenmesi şüphesiz ki programların daha etkili ve verimli olmasını etkileyecek ve daha sonraki zamanlarda yapılacak olan program geliştirme çalışmalarına öncülük edecektir. Ayrıca lisans programlarının etkili ve verimli olmasında en büyük rol şüphesiz ki bu dersleri veren akademisyenlere aittir. Akademisyenlerin yeni lisans programlarının ders içerikleri hakkında ne düşündükleri bu programların daha verimli hale gelmesi için yapılabilecek düzenlemelerde önemli bir veri sağlayabilir. Ayrıca yeni bir uygulama olan bu programların ve ders içeriklerinin değerlendirilmesi hakkında çok az çalışmaya rastlanılmış olması araştırmanın önemini daha da artırmaktadır. Bu çalışmada, eski sınıf öğretmenliği programındaki alan derslerinin (Genel Fizik, Genel Kimya ve Genel Biyoloji) kaldırılarak, bu derslerin konularının yeni programda sadece bir dönemde İlkokulda Temel Fen Bilimleri dersi adı altında verilmesi ile ilgili olarak akademisyenlerin görüş ve değerlendirilmesinin ortaya konulması amaçlanmıştır. Bu amaç doğrultusunda şu sorulara cevap aranmıştır:

1. YÖK tarafından güncellenen yeni öğretmenlik lisans programları hakkındaki görüşleriniz nelerdir?

2. Daha önce sınıf öğretmenliği programında yer alan Genel Fizik, Genel Kimya ve Genel Biyoloji alan derslerinin müfredattan kaldırılarak ve bu derslerin özet bir şekilde İlkokulda Temel Fen Bilimleri dersi adı altında ve tek bir dönemde verilmesini doğru buluyor musunuz?

3. Fen Bilimleri alan dersleri (Genel Fizik, Genel Kimya, Genel Biyoloji) yerine sadece İlkokulda Temel Fen Bilimleri dersini alan sınıf öğretmeni adaylarının yeterli fen bilimleri donanımına sahip olacağını düşünüyor musunuz?

4. Fen Bilimleri alan derslerini (Genel Fizik, Genel Kimya, Genel Biyoloji) alamayan sınıf öğretmeni adaylarının 21. yüzyıl becerilerine sahip öğrenciler yetiştirebileceklerine inanıyor musunuz?

5. Size göre İlkokulda Temel Fen Bilimleri dersinin içeriğine başka hangi konu başlıkları eklenmelidir? 


\section{Yöntem}

Eski programdaki alan derslerinin tüm konularını içeren ve yeni programda sadece bir dönemde verilecek olan İlkokulda Temel Fen Bilimleri dersi hakkında akademisyenlerin görüş ve değerlendirilmesinin ortaya konulmasının amaçlandı̆̆ çalışma temel nitel bir araştırmadır. Merriam (2013)'a göre bir kimse fenomenolojik, etnografik, öyküsel analiz, gömülü teori kapsamına girmeyen nitel bir çalışma yapabilir ve tüm nitel araştırmalar yorumlamaya dayalı olduğu için bu tür çalışmalar "temel nitel araştırma" olarak adlandırılır. Temel nitel araştırma yapan araştırmacılar insanların hayatlarını nasıl yorumladıklarını ve deneyimlerine ne anlam kattıklarını araştırmak ve bu anlamları ortaya çıkarmak için uğraşırlar. Bu amaçla veriler doküman analizi, gözlem veya görüşmeler yoluyla toplanır (Merriam, 2013). Dolayısıyla nitel araştırma desenlerinden hiçbirinin kapsamına tam olarak uymayan bu çalışmada görüşme yoluyla akademisyenlerin İlkokulda Temel Fen Bilimleri dersi hakkındaki görüşleri belirlenmeye çalışılmıştır.

\section{Çalışma Grubu}

Araştırmanın çalışma grubunu 2018-2019 eğitim öğretim yılı bahar döneminde Firat ve İnönü üniversitelerinde görev yapan ve görüşme yapmayı kabul eden 10 öğretim üyesi oluşturmaktadır. Amaçlı örnekleme yöntemlerinden ölçüt örnekleme yöntemi kullanılarak katılımcılar belirlenmiştir. Bu örnekleme yönteminde, önceden belirlenmiş bir dizi ölçütü karşılayan tüm durumlar çalışılır. Belirlenecek olan ölçüt ya araştırmacı tarafından ya da hazır ölçüt listesi kullanılarak belirlenir (Yıldırım ve Şimşek, 2008). Bu çalışmada ise çalışma grubunu belirlemede alınan ölçüt araştırmacılar tarafından çalışmanın amacına uygun olarak belirlenmiştir. Ölçüt ise; bu çalışmaya katılan akademisyenlerin Eğitim Fakültelerinin Matematik ve Fen Bilimleri Eğitimi ve Temel Eğitim bölümlerinde görev almaları ve sinıf öğretmenliği programındaki fen derslerine girmiş olmalarıdır. Çünkü sınıf öğretmenliği programındaki fen derslerine genellikle Temel Eğitim bölümünde uzmanlığı fen eğitimi alanında olan veya Matematik ve Fen Bilimleri Eğitimi bölümü Fen Bilgisi Eğitimi Anabilim Dalında görev alan akademisyenler girmektedir. Bu akademisyenlerin görüşünün alınması çalışmanın daha sağlıklı yürütülmesi açısından önemlidir. Ayrıca araştırmanın etiği açısından araştırmaya katılan akademisyenlerin isimlerine yer verilmemiştir. Örneklemi oluşturan akademisyenler kendi içlerinde rakamlarla kodlanmış ve "A" harfi ile temsil edilmişlerdir (A1, A2, A3,.....A9, A10). Araştırmaya katılan akademisyenlerin demografik özelliklerine Tablo 2'de yer verilmiştir.

Tablo 2 incelendiğinde katılımcıların altısı erkek, dördü bayandır. Yaşları 34-65 arasında; kıdem yılları ise 9-43 yıl arasında değişmektedir. Katılımcıların altısı doktor unvanına, ikisi doçent unvanına, ikisi de profesör unvanına sahiptir. Akademisyenlerin ikisi Temel Eğitim; geriye kalan sekizi de Matematik ve Fen Bilimleri Ĕ̆itimi bölümünde görev yapmaktadır. 
Tablo 2

Araştırmaya Katılan Akademisyenlerin Demografik Özellikleri

\begin{tabular}{llllll}
\hline Katılımcılar & Cinsiyet & Yaş & Mesleki Kıdem Yılı & Unvan & Görev Yapılan Bölüm \\
\hline A1 & Erkek & 43 & 19 & Prof. Dr. & Matematik ve Fen Bilimleri Eğitimi \\
A2 & Bayan & 52 & 20 & Dr. & Matematik ve Fen Bilimleri Eğitimi \\
A3 & Bayan & 44 & 20 & Dr. & Matematik ve Fen Bilimleri Eğitimi \\
A4 & Bayan & 39 & 16 & Dr. & Matematik ve Fen Bilimleri Eğitimi \\
A5 & Erkek & 65 & 43 & Prof. Dr. & Matematik ve Fen Bilimleri Eğitimi \\
A6 & Bayan & 39 & 16 & Dr. & Matematik ve Fen Bilimleri Eğitimi \\
A7 & Erkek & 42 & 17 & Doç. Dr. & Temel Eğitim \\
A8 & Erkek & 41 & 18 & Doç. Dr. & Matematik ve Fen Bilimleri Eğitimi \\
A9 & Erkek & 34 & 9 & Dr. & Matematik ve Fen Bilimleri Eğitimi \\
A10 & Erkek & 39 & 15 & Dr. & Temel Eğitim \\
\hline
\end{tabular}

\section{Veri Toplama Araçları}

Araştırma verilerinin toplanılmasında nitel veri toplama yöntemlerinden görüşme yöntemi kullanılmıştır. Bu amaçla araştırmacılar tarafından yarı yapılandırılmış görüşme formu hazırlanmıştır. Wengraf (2001)'a göre yarı yapılandırılmış görüşme; görüşme sırasında ihtiyaç duyulması halinde, soruların yeniden düzenlenmesine imkân verdiğinden nitel araştırmalarda çok tercih edilmektedir. Görüşme formu hazırlanmadan önce ilk olarak araştırmacılar tarafından araştırma konusuyla ilgili genel bir alan yazı taraması yapılmış ve taslak bir görüşme formu hazırlanmıştır. Taslak görüşme formunun çalışmanın amacına uygunluğu ve soruların anlaşılırlığ bakımından Matematik ve Fen Bilimleri Eğitimi bölümündeki iki akademisyenin görüşlerine başvurulmuştur. Akademisyenler soruları genel olarak çalışmanın amacına uygun ve anlaşılır bulmuştur. Böylece görüşme formuna son hali verilmiştir. Görüşme formu üç kısımdan oluşmaktadır. Birinci bölümde yönerge kısmı vardır. Yönerge kısmında, katılımcılara araştırmanın amacı açıklanarak araştırmanın amacına ulaşması için soruları samimi bir şekilde cevaplamaları istenmiştir. İkinci bölümde örneklemi oluşturan akademisyenlerin kişisel bilgilerine (cinsiyet, yaş, mesleki kıdem yılı, unvan, görev yapılan bölüm) yer verilmiştir. Üçüncü bölümde ise İTFB dersine yönelik akademisyen görüşlerini belirlemek adına beş soru yer almaktadır. Katılımcılar ile yüz yüze görüşme yapılmış olup sorulara verdikleri cevaplar yazıya aktarılmıştır. Görüşmeler, akademisyenlerin uygun oldukları zamana randevu alınarak ofislerinde, sessiz bir ortamda ve her iki araştırmacının katılımıyla yapılmış olup ortalama 35 dakika sürmüştür.

Güvenirlik ve geçerlik. Bu çalışmanın geçerlik ve güvenirliğini artırmak için Lincoln ve Guba (1985) tarafından önerilen ve nitel araştırmanın niteliğini artıracak olan inandırıcilik, aktarılabilirlik, tutarlık ve teyit edilebilirlik stratejileri kullanılmıştır. Çalışmanın inandırıcılığı uzman incelemesi ve katılımcı teyidi ile sağlanmıştır. Bu amaçla görüşme formu hakkında Fen Bilimleri Eğitimi Anabilim Dalında görevli iki akademisyenin görüşlerine başvurulmuştur. Katılımcı teyidini sağlamak için de araştırmacı görüşme sonunda topladı̆̆ı verileri özetleyerek katılımcılardan kendi algısının verileri doğru yansıtıp yansıtmadığını kontrol etmelerini istemiştir. Çalışmanın aktarılabilirliğini sağlamak için ise yapılan çalışma, katılımcılar ve araştırmanın yapıldığı yer ile ilgili detaylı bilgiler verilmiştir. Böylece okuyucunun verilerin elde edildiği ortamı zihninde canlandırması sağlanmıştır. Araştırmanın 
tutarlılığını sağlamak adına aynı veriler iki araştırmacı tarafından tek tek analiz edilip kodlanmıştır. Verilerin kodlanması aşamasında, Strauss ve Corbin (1990) tarafından bahsedilen üç çeşit kodlama türünden biri olan verilerden çıkarılan kavramlara göre kodlama yapılmıştır. Bu amaçla her bir araştırmacı, elde ettiği verileri incelemiş, anlamlı bölümlere ayırmış ve her bölümün kavramsal olarak ne anlama geldiğini bulmaya çalışmıştır. Dolayısıyla her bir görüşme sorusu için araştırmacılar tarafından kodlar oluşturulmuştur. Daha sonra ise araştırmacılar arasındaki uyum oranını belirlemek için Miles ve Huberman (1994) tarafından ortaya konan güvenirlik formülü (Görüş Birliği/(Görüş Birliği+Görüş Ayrılığı)x100) kullanılmıştır. Araştırmacılar arasındaki uzlaşma yüzdesi \%85 olarak hesaplanmıştır. Hesaplanan yüzdenin $\% 70$ ve üzeri olması verilerin analiz güvenirliğini sağlamak için yeterlidir (Yıldırım ve Şimşek, 2011). Bununla birlikte katılımcı ifadelerine doğrudan alıntılama yapılarak da çalışmanın teyit edilebilirliği sağlanmıştır.

\section{Verilerin Analizi}

İçerik analizi yöntemi kullanılarak veriler analiz edilmiştir. Yıldırım ve Şimşek (2006)'e göre bu analiz türünde yapılan temel işlem benzerlik gösteren verileri belirli kavramlar ve temalar etrafında bir araya getirerek bunları okuyucunun anlayabileceği şekilde düzenleyip yorumlamaktır. İçerik analizine öncelikle verilerin kodlanması aşaması ile başlanmıştır. Oluşturulan bu kodlar çerçevesinde aşağıdaki kategoriler (temalar) ortaya çıkmıştır. Ayrıca bu çalışmada asıl ortaya konulmak istenen temel temanın ITFB Dersinin Değerlendirilmesi olduğu vurgulanmıştır.

- Güncellenen Yeni Öğretmenlik Lisans Programları Hakkındaki Genel Görüş

- İTFB Dersine İlişkin Genel Görüş

- ITFB Dersini Alan Öğretmen Adaylarının Fen Bilgisi Alan Yeterliliği

- Sınıf Öğretmeni Adaylarının 21. Y.Y. Becerilerine Sahip Öğrenciler Yetiştirme Durumu

- ITTFB Dersinin İçeriğine Eklenmesi Gereken Konu Başlıkları

\section{Araştırmanın Sınırlılıkları}

Bu araştırma, 2018-2019 eğitim öğretim yılı bahar döneminde Fırat ve İnönü Üniversitelerinde görev yapan 10 öğretim üyesi ve öğretim üyelerine uygulanan yarı yapılandırılmış görüşme formlarından elde edilen verilerin araştırmacılar tarafından yapılan içerik analizi ile sınırlıdır. Farklı örneklem grupları üzerinde farklı araştırmacılar tarafından farklı veri toplama araçları kullanılarak yapılan çalışmalar farklı sonuçlar verebilir.

\section{Bulgular}

Çalışmanın bulguları araştırma problemleri odaklı hazırlanan görüşme formundan elde edilen verilerin analizi yapılarak oluşturulmuştur. Çalışma bulguları beş kategorik başlık altında verilmiştir. Bu kategoriler ise akademisyenlerin görüşme sorularına verdikleri cevaplardan oluşturulan kodları içermektedir. Ana tema etrafında oluşturulan kategoriler ve bu kategorilere ilişkin kodlar Tablo 3'deki gibi oluşturulmuştur. 
Tablo 3

Çalışmada Elde Edilen Kategoriler ve Kodlar

\begin{tabular}{llr}
\hline Kategoriler & Kodlar & $\mathrm{f}$ \\
\hline a) Güncellenen Yeni Öğretmenlik & Alan eğitimine yönelik derslerin azaltılması & 4 \\
Lisans Programları Hakkındaki & Alan bilgisi yetersiz öğretmen adaylarının yetişmesi & 3 \\
Genel Görüş & Yöntemi bilmesinin yeterli olması & 1 \\
& Paydaş görüşlerin ve alan yazındaki çalışmaların dikkate & 1 \\
& alınmaması & \\
b) İTFB Dersine İlişkin Temel Görüşs & Ders saatinin yetersiz olması & 4 \\
& Alanında donanımsız öğretmenlerin yetişmesi & 3 \\
& Fen okur-yazar birey yetişmemesi & 1 \\
c) İTFB Dersini Alan Öğretmen & Yeterli donanıma sahip olunmaması & 4 \\
Adaylarının Fen Bilgisi Alan & Fen bilimleri dersinin uzmanlar tarafından ayrı ayrı verilmesi & 1 \\
Yeterliliği & Uluslararası sınavlardaki başarının etkilenmesi & 1 \\
d) Sınıf Öğretmeni Adaylarının 21. & Sahip olunan bilginin aktarılması & 3 \\
Yüzyıl Becerilerine Sahip Öğrenciler & Ustası yetersiz çırak yetişmesi & 2 \\
Yetiştirme Durumu & Fen okur-yazar birey yetişmemesi & 1 \\
e) İTFB Dersinin İçeriğğine Eklenmesi Başka konuların eklenmesinin sorunu çözmemesi & 2 \\
Gereken Konu Başlıkları & İkokul fen müfredatındaki konuların eklenmesi & 1 \\
& Temel süreç becerilerinin eklenmesi & 1 \\
& Biyoloji konularının artırılması & 1 \\
\hline
\end{tabular}

\section{a) Güncellenen Yeni Öğretmenlik Lisans Programları Hakkındaki Genel Görüş}

Çalışmaya katılan akademisyenlere araştırmanın ilk sorusu olarak "YÖK tarafından güncellenen yeni öğretmenlik lisans programları hakkındaki görüşleriniz nelerdir?" sorusu sorulmuştur. Bu soruya akademisyenlerin verdikleri cevaplara göre Alan Eğitimine Yönelik Derslerin Azaltılması, Alan Bilgisi Yetersiz Öğretmen Adaylarının Yetişmesi, Yöntemi Bilmesinin Yeterli Olması, Paydaş Görüşlerin ve Alan Yazındaki Çalışmaların Dikkate Alınmaması kodları oluşturulmuştur.

\section{Alan Ĕ̆itimine Yönelik Derslerin Azaltılması}

$\mathrm{A}_{3}$ : "Alan eğitimine yönelik derslerin oranının azalmasını sağlıksız buluyorum. Eksik bilgilerin ileride daha büyük problemlere sebep olacağını düşünüyorum."

$\mathrm{A}_{4}$ : "Dağılımın uygun olmadığını düşünüyorum. Alan eğitimine yönelik derslerin azaltılmasını doğru bulmuyorum."

A9: "Alan bilgisi öğretmenlerin öğretmekten sorumlu oldukları bilgilerdir. Dolayısıyla bu bilgilerin programda azaltılması bana göre uygun değildir."

$\mathrm{A}_{10}$ : "Girdiğimiz derslerde net bir şekilde gördüğümüz; öğrencilerin alan bilgisinde ciddi eksikliklerinin olmasıdır. Çoğu zaman anlattı̆̆ımız konular hakkında bilgi sahibi olmayı bırakın, ilk kez duyduklarını ifade etmektedirler. Alan derslerinin azaltılması ciddi bir hata olmuş."

\section{Alan Bilgisi Yetersiz Öğretmen Adaylarnnın Yetișmesi}

$\mathrm{A}_{1}$ : "Alan dersleri eski müfredatta bile yetersizdi. Özellikle fizik dersinin ders saati konuları yetiştirmeye yetmiyordu. Son haliyle bu ders müfredattan çıkarıldı. Yeni dağılım ile alan bilgisi yetersiz öğretmen adaylarının yetişeceği aşikârdır." 
$\mathrm{A}_{6}$ : "Alan eğitimine yönelik dersler eski haliyle bile yetersiz geliyordu. Bu haliyle öğretmen adaylarının yetersiz alan bilgisi ile mezun olacağı ortadadir."

A8: “2018 Dünya Ekonomik Forum raporuna göre Matematik ve Fen Eğitimi kalitesinde Türkiye 104. sıradadır. TIMSS ve PISA sonuçları da bunu teyit etmektedir. Bu tablo sınıf öğretmenlerimizin alan ve alan eğitimi bilgilerinin yetersizliğinin bir sonucudur. Yeni lisans programı bilimsel ilkeleri temel alan, sorunu çözme niyetinden çok uzak bir programdır."

\section{Yöntemi Bilmesinin Yeterli Olması}

$\mathrm{A}_{5}$ : "Bu programların hazırlanmasında görev alan uzmanların alan eğitiminden olmayışının (varsa da çok az) etkisiyle adeta yöntemi bilirse alanı bilmese de olur görüşü ağır basmaktadır. Oysa bir öğretici yöntemi bilse bile bilmediği bir konuyu nasıl öğretir?"

\section{Paydaş Görüşlerin ve Alan Yazındaki Çalışmaların Dikkate Alınmaması}

$\mathrm{A}_{2}$ : "Yeni programdaki dağılım ne yazık ki paydaşların görüşleri ve alan yazındaki çalışmalar dikkate alınmadan yapılmıştır. 21. Yüzyıl yetkinlik ve becerilerine sahip öğretmen yetiştirebilecek bir lisans programı değil. Alan yazın tarandığında temel sorunun mesleki formasyon ve öğretmenlik uygulaması ders saatlerinin artırılması gerektiği şeklinde değerlendirmeler yoğunluktadır. Ama önceki program ile karşılaştırdığımızda bu yönde değişen pek bir şeyin olmadığını görüyoruz."

$\mathrm{Bu}$ kategori çerçevesinde akademisyenlerin görüşlerine bakıldığında; akademisyenlerin yeni lisans programının dağılımını uygun bulmadığı, dolayısıyla bu dağılımın getirebileceği sorunlar üzerinde yoğunlaştıkları görülmektedir.

\section{b) İTFB Dersine İlişkin Genel Görüş}

Akademisyenlere araştırmanın ikinci sorusu olarak “Daha önce sınıf öğretmenliği programinda yer alan Genel Fizik, Genel Kimya ve Genel Biyoloji alan derslerinin müfredattan kaldırılarak ve bu derslerin özet bir şekilde İlkokulda Temel Fen Bilimleri dersi adı altında ve tek bir dönemde verilmesini doğru buluyor musunuz?" sorusu sorulmuştur. Bu soruya akademisyenlerin verdikleri cevaplara göre Ders Saatinin Yetersiz Olması, Alanında Donanımsız Öğretmenlerin Yetişmesi, Fen Okur-Yazar Birey Yetişmemesi kodları oluşturulmuştur.

\section{Ders Saatinin Yetersiz Olması}

A9: "Fizik, kimya ve biyoloji dersleri kapsamlı derslerdir ve bu üç dersin tek bir dönemde özet bir şekilde verilmesi mümkün görülmemektedir. Bir öğretmen adayı bir dönemde hangi fen dersinin hangi konularını öğrenebilecektir? Fen Bilimlerini öğrenme açısından bu üç dersin yeniden programa yerleştirilmesi gerekir."

$A_{7}:$ "Eski programlar ağırdı. Sınıf öğretmenliği yapacak birisi için çok fazla bilgi içeriyordu. Bu yüzden bir düzenleme yapılması gerekiyordu. Ancak bu kez de her bir derse ortalama 4 hafta düşmesi ve tek bir dönemde verilmesi öğretmen adaylarında yetersiz alan bilgisi oluşturacağını düşünmekteyim." A6: "Eski müfredatta öğrenciler fen alan bilgisini yeterince almadan, tam olarak özümseyemeden öğretmen oluyordu. Bu durumda üç ayrı ders tek bir ders altında ve daha az ders saati ile verilmeye çalışılacak. Bu kısa sürede fen bilimlerinin temel kavramlarının öğretilmesinden ileriye gidilmeyecektir." 
$\mathrm{A}_{2}$ : “Doğru değil. Eğer bilim ve teknolojinin şekillendirdiği ve hayatımızı yönlendirdiği bir çağda yer edinmek istiyorsak önce okul öncesinden başlayarak öğrencilere araştıran, sorgulayan, bilimsel düşünebilen bireyler yetiştirmemiz gerekir. Haftada üç saatle Fizik, Kimya, Biyoloji, Yer Bilimleri ve Sağlık gibi konuların kavratılabilmesi mümkün değil. Ama bizler bilgi sahibi olmadan fikir sahibi olmaya alışı̆̆ız. O nedenle böyle bir değişikliğe gidilmiş olabilir."

\section{Alanında Donanımsız Öğretmenlerin Yetișmesi}

$\mathrm{A}_{1}$ : “Bu derslerin kaldırılmasını kesinlikle doğru bulmuyorum. İlkokuldaki öğrenciler çevresine karşı daha meraklıdırlar. Bu nedenle çok fazla sorular sorarak meraklarını gidermeye çalışırlar. Fizik, Kimya ve Biyoloji alan derslerinde gerekli temel bilgileri alamayan bir öğretmen öğrencilerine yetmeyecek ve öğrencilerde ileride yeri doldurulamayacak eksikliklere neden olacaklardir."

A8: "Alan bilgisi zayıf olan bir öğretmenin yeterlik sahibi olması mümkün değildir. Bu program mevcut tabloyu daha da geriye götürecektir."

$\mathrm{A}_{10}$ : "Daha önceki müfredatta sınıf öğretmeni adayları fizik, kimya ve biyoloji derslerini detaylı bir biçimde alıyordu. Lisede yeterli temel fen bilimleri dersi almadan gelen bu öğrenciler için bu dersler çok önemliydi. Eksiklikleri üniversitede kapatılıyordu. Yeni sistemde çok yüzeysel ve yetersiz bir durumda."

\section{Fen Okur-Yazar Birey Yetișmemesi}

A4: “Özet yapılmasını doğru bulmuyorum. Ülkemizde fen bilimleri alanında yetişmiş insan sayısının yetersiz olduğunu, bu alanda bilgili insan sayısını az buluyorum. Sorgulayan, araştıran, düşünen bireylere ihtiyaç olduğunu, Fen'in bu anlamda kişiye başka bir ufuk açtığını, farklı bakış açıları kazandırdığını, doğayı-dünyayı-hayatı anlama ve anlamlandırmada çok büyük bir rol oynadığına inanıyorum. Bunların eksik olduğu birey toplum hayatın her alanında zorluk yaşayacak ve insanlığın hak ettiği yaşam koşullarından mahrum kalacaktır."

$\mathrm{Bu}$ kategori çerçevesinde akademisyenlerin görüşlerine bakıldığında; akademisyenlerin daha çok İTFB dersinin ders içeriği ve ders saatinin yeterli olmadı ̆̆ üzerinde yoğunlaştıkları görülmektedir.

\section{c) İTFB Dersini Alan Öğretmen Adaylarının Fen Bilgisi Alan Yeterliliği}

Akademisyenlere araştırmanın üçüncü sorusu olarak "Fen Bilimleri alan dersleri (Genel Fizik, Genel Kimya, Genel Biyoloji) yerine sadece İlkokulda Temel Fen Bilimleri dersini alan sınıf öğretmeni adaylarının yeterli fen bilimleri donanımına sahip olacağını düşünüyor musunuz?" sorusu sorulmuştur. Bu soruya akademisyenlerin verdikleri cevaplara göre Yeterli Donanıma Sahip Olunmaması, Fen Bilimleri Dersinin Uzmanlar Tarafindan Ayrı Ayrı Verilmesi, Uluslararası Sınavlardaki Başarının Etkilenmesi kodları oluşturulmuştur.

\section{Yeterli Donanıma Sahip Olunmaması}

A6: "Bir öğretmen öğrencilerine vereceği bilgiden fazlasına sahip olmalıdır. Çok fazla konuda bilgi sahibi ve donanımlı olmalıdır. İlkokulda Temel Fen Bilimleri dersi fen bilimlerine giriş niteliğinde bir ders olarak görülmektedir. 
İlkokul düzeyindeki bir öğrencinin müfredat dışında soracağı bir soruya bile cevap veremeyecek öğretmenler yetiştirme ihtimali ortaya çıkmaktadır."

A9: "Bu derslerin yerine temel fen bilimleri dersi alan öğretmen adaylarının yeterli fen bilimleri donanımına sahip olacağını düşünmüyorum. Çünkü bu dersler hayatın içinden konuları kapsamakla birlikte birçok yasa ve teorinin olduğu derslerdir. Temel anlamda anlamak bile bir dönemde yeterli olmaz." A5: "Hayır, düşünmüyorum. Öyle olsaydı ilkokulu bitiren birinin ilkokula öğretmen olmasının bir sakıncası olmazdı. Ortaokul, lise, üniversite eğitimi almanın zorunlu olması sadece bazı öğretim yöntemlerini (bu da genel öğretim yöntemleri) kazandırmak için midir? Genel kültür denilen kültür içinde Fizik, Kimya, Biyoloji kültürü yok mudur? Elektrik çarpmasının nedeni ve vücutta oluşturacağı tahribat veya yanmanın mekanizması, oluşan gazların etkisi genel kültür değil midir ki bunlar olmadan genel kültür artıriliyor."

A4: "Fen Bilimleri alan derslerinin tek bir derse sı̆̆dırılmaya çalışılmasını doğru bulmuyorum. Bu dersi alan öğretmenlerin Fen Bilimleri alan derslerinde yeterli olmayacağını düşünüyorum. Her bir dersin kendi içinde öğrenilmesi gereken konuların azaltılacağını, bu durumda derslerin temellerinin yeterli öğrenilemeyeceğini düşünüyorum. Sınıf öğretmenlerinin kişinin hayatında çok önemli bir rol üstlendiği gerçeği aşikârdır. Bu kadar önemli bir noktada bulunan kişilerin Fen Bilimleri alanında yetersiz olmasına yol açacağını, dolayısıyla da yetiştirilen öğrencilerin de yetersiz olacağını düşünüyorum."

\section{Fen Bilimleri Dersinin Uzmanlar Tarafindan Ayrn Ayru Verilmesi}

$\mathrm{A}_{3}:$ “Düşünmüyorum. Müfredat değişmeden önceki halinde bile ders saatinin yetersiz olduğuna inanıyordum. Fen Bilimleri dersinin uzmanlar tarafından ayrı ayrı verilmesinin bilginin aktarılması, kalıcılığı ve güvenirliği açısından daha iyi olacağını düşünüyorum."

\section{Uluslararası Sınavlardaki Başarının Etkilenmesi}

$\mathrm{A}_{2}$ : "Bir dersin içeriğini, özünü bilmeden onu en etkili bir şekilde nasıl öğreteceğimizi bilmemiz mümkün değil. Bunu başkalarının yaptıklarını mevcut koşullar, özellikler göz önünde bulundurulmadan kopya uygulamalarla başardığımızı zannediyoruz. Ama PISA, TIMSS gibi uluslararası sınavlardaki başarımız ortada. Tekrar ediyorum "Bilgi sahibi olmadan fikir sahibi olunamaz."

$\mathrm{Bu}$ kategori çerçevesinde akademisyenlerin görüşlerine bakıldı̆̆ında; akademisyenlerin sadece İTFB dersini alan sınıf öğretmeni adaylarının alanlarında yeterli donanıma sahip olamayacakları, bu durumun zaten düşük olan uluslararası sınavlardaki başarımızı daha da düşüreceği, Fen Bilimleri dersinin her alanının uzmanlar tarafından verilmesi gerektiği düşüncesinde oldukları görülmektedir.

\section{d) Sınıf Öğretmeni Adaylarının 21. Y.Y. Becerilerine Sahip Öğrenciler Yetiştirme Durumu}

Akademisyenlere araştırmanın dördüncü sorusu olarak “Fen Bilimleri alan derslerini (Genel Fizik, Genel Kimya, Genel Biyoloji) alamayan sınıf öğretmeni adaylarının 21. Yüzyıl becerilerine sahip öğrenciler yetiştirebileceklerine inanıyor musunuz?" sorusu sorulmuştur. Bu soruya akademisyenlerin verdikleri cevaplara göre Sahip Olunan 
Bilginin Aktarılması, Ustası Yetersiz Çırak Yetişmesi, Fen Okur-Yazar Birey Yetişmemesi kodları oluşturulmuştur.

\section{Sahip Olunan Bilginin Aktarilması}

$\mathrm{A}_{3}:$ "Hayır inanmıyorum. Bilginin aktarımı ancak bu beceriye sahip olmuş kişiler tarafından yapılabilir."

$\mathrm{A}_{5}$ : "İnanmiyorum. Kişi kendi becerisi olmayan bir konuda başkasına beceri kazandırabilir mi? Eğer yapabilirse o zaman herkes her alanda öğretmenlik yapabilir."

A10: "Kendisinin dahi bilmediği, anlamadığı fen konularını öğrencilere öğretmeleri mümkün değil."

\section{Ustası Yetersiz Çırak Yetişmesi}

$\mathrm{A}_{4}$ : "Yetersiz öğretmenlerin 21. yüzyıl becerilerine sahip öğrenciler yetiştirebileceklerine inanmıyorum. Öğreticisi, rehberi yetersiz kişi başarılı olamaz. Ustası yetersiz çırakların çok çok zorlasak \%50 den fazlası başarılı olmaz. İstisnai olarak kişinin kendisinde olan meziyetler sayesinde başarılı olabileceği durumlar vardır. Ama bunlar az önce dediğimiz gibi istisnai durumlardir."

$\mathrm{A}_{1}$ : “Kesinlikle inanmiyorum. Geliştirilen teknoloji ve yenilikler temel fen bilimleri sayesinde olmaktadır. Lisans döneminde bu dersleri tam anlamıla görmeyen öğrencilerin bu bağlamda ders anlatmaları, örneklendirmeleri yeterli olmayacak ve ülkemizde geleceğin teknolojilerini üretebilecek öğrencilerin yetişmesine vesile olamayacaklardır."

Fen Okur-Yazar Birey Yetişmemesi

A6: “Günümüzde çocuklar bilgiye kolay ulaşabilmeleri (tablet, tlf, pc aracılığ1 ile) nedeniyle birçok alanda bilgi sahibi olabilmekte bu da onların merakını ve daha fazla bilgiye ulaşma isteklerini artırmaktadır. Öğretmenlerin de bu çocukların ihtiyaç ve meraklarını karşılayabilecek nitelikte ve donanımda olması gerekir. Fen okuryazarlığı da 21. Yüzyıl becerilerinin başında gelmektedir. Tüm öğrencilerin en azından en temel düzeyde fen kavramlarını ve olgularını anlayabilmesi gerekmektedir. Fen alan bilgisi yetersiz bir öğretmenin fen okur-yazar öğrenciler yetiştirmesi mümkün değildir."

$\mathrm{Bu}$ kategori çerçevesinde akademisyenlerin görüşlerine bakıldı̆̆ında; akademisyenlerin, yeterli alan donanımına sahip olmayan öğretmenlerin sadece bildiklerini öğrencilerine aktaracağından öğrencilerinin de yeterli donanıma sahip olamayacağı, dolayısıyla fen okur-yazar bireyler yetişemeyeceği düşüncesinde oldukları görülmektedir.

\section{e) İTFB Dersinin İçeriğine Eklenmesi Gereken Konu Başlıkları}

Akademisyenlere araştırmanın son sorusu olarak "Size göre İlkokulda Temel Fen Bilimleri dersinin içeriğine başka hangi konu başlıkları eklenmelidir?" sorusu sorulmuştur. Bu soruya akademisyenlerin verdikleri cevaplara göre Başka Konuların Eklenmesinin Sorunu Çözmemesi, İlkokul Fen Müfredatındaki Konuların Eklenmesi, Temel Süreç Becerilerinin Eklenmesi, Biyoloji Konularının Artırılması kodları oluşturulmuştur.

\section{Baska Konuların Eklenmesinin Sorunu Cözmemesi}

$\mathrm{A}_{6}$ : “Bu dersin içeriğine başka konuların eklenmesi sorunun çözümüne katk1 sağlamayacaktır. Ders süresi ancak mevcut konuların işlenmesine yetecektir. $\mathrm{Bu}$ ders Fen Bilimlerine giriş dersi niteliğinde kalıp fizik, kimya ve biyoloji 
derslerinin ayrıca verilmesi gerekmektedir. Bu dersi hangi alanda uzman öğretim elemanının vereceği de ayrı bir tartışma konusudur."

$\mathrm{A}_{1}$ : "Bu derse konu başlıkları eklemenin çözüm olmayacağı kanaatindeyim. Yapılan bu değişikliklerin tekrar detaylı bir şekilde gözden geçirilmesi gerekir."

\section{İlkokul Fen Müfredatındaki Konuların Eklenmesi}

A4: “Staja giden öğrencilerimizden aldığımız dönütlerinden bazıları şunlardır: Üniversitede aldıkları fen eğitiminin çok yetersiz olduğu, MEB'in kitapları incelendiğinde öğretmen adaylarının yeterli alt yapıya sahip olmadikları... Bu durumda mevcut sistem bile yetersiz iken İlkokulda Temel Fen Bilimleri dersinin (içeriğinin ve ders saatinin azaltıldığı) bu ihtiyacı hiç karşılamadığı-karşılamayacağı aşikârdır. Eklenecek konu başlıklarına gelince şuan için MEB'in programindakilerin eklenmesi ve derhal ders saatlerinin artırılması kısmen de olsa mevcut eksikliği giderebilecektir."

Temel Süreç Becerilerinin Eklenmesi

A9: "Bence temel süreç becerilerinin de dâhil edilmesi iyi olur."

\section{Biyoloji Konularnin Artırılmast}

$\mathrm{A}_{10}$ : "Canlının temel taşı olan hücreyi tanımalı. Çevresindeki canlıları tanımalı (bitki, hayvan, omurgasızlar vb.) bu canlının beslenmesi, hareketi ve enerji elde etme yolları hakkında fikir sahibi olmalı. Temel besin maddeleri olan protein, karbonhidrat ve yağlar, dengeli beslenme hakkında bilgi sahibi olmalı. Fotosentezi, besin piramidini, organ ve sistemleri ve sistemlerin çalışması hakkında fikir sahibi olmalı."

$\mathrm{Bu}$ kategori çerçevesinde akademisyenlerin görüşlerine bakıldı̆̆ında; akademisyenlerin bir kısmı bu derse farklı konu başlıkları eklenmesinin var olan sorunu çözemeyeceği konusunda görüş bildirirken bir kısmı da temel süreç becerilerinin eklenmesi, biyoloji konularının artırılması ve içeriğin ilkokul fen müfredatıyla uyumlu hale getirilmesi konusunda görüş bildirmişlerdir.

\section{Tartışma, Sonuç ve Öneriler}

Bu çalışmada 2018-2019 eğitim-öğretim yılında güncellenen yeni sınıf öğretmenliği lisans programında yer alan İTFB dersi akademisyen görüşlerine göre incelenmiştir. Çalışma verilerinden elde edilen bulguların ortaya koyduğu sonuçlara baktığımızda;

Güncellenen Yeni Öğretmenlik Lisans Programı Hakkındaki Genel Görüş temasında, akademisyenlerin genel olarak programın dağılımını uygun bulmadığı görülmektedir. Akademisyen görüşlerine bakıldığında, katılımcıların özellikle programlardaki alan derslerinin azaltılmasının getireceği sorunlar üzerinde yoğunlaştığ1 görülmektedir. Akademisyenlerden bazıları program güncellenirken paydaş görüşlerin ve alan yazındaki çalışmaların yeterince dikkate alınmadığ düşüncesindedirler. Alan yazı taraması yapıldığında, öğretmen eğitimi sürecinde alan bilgisinin mi yoksa öğretmenlik meslek bilgisinin mi ağırlıklı olması gerektiği konusunda bir tartışma söz konusudur. Yıldırım (2011)'a göre aslında bu sorunun cevabı öğretmene yüklenen anlamla ilişkilidir. Konu alanı anlayışına göre nitelikli öğretmen yetiştirmek için alan eğitimine önem verilmelidir. Bu anlayışta öğretmen adayı mesleğini icra etmeye başladığı zaman zaten öğretmenlik meslek bilgisine sahip olacağı, önemli olanın derin bir alan bilgisine sahip olmasıdır. Öğretmenlik meslek bilgisi anlayışına göre ise, nitelikli öğretmen demek derse uygun yöntem ve teknikleri 
kullanarak eğitim sürecine hâkim olan kişi demektir. Kennedy, Ahn ve Choi (2008)'ye göre bir öğretmen alanında ne kadar donanımlı olursa olsun, sahip olduğu bilgiyi nasıl öğreteceğini bilmiyorsa sahip olduğu bilgiyi de öğretemez düşüncesiyle öğretmenlik meslek bilgisinin önemini vurgulamaktadır. Taş, Kunduroğlu Akar ve Kıroğlu (2017)'nun eski sınıf öğretmenliği lisans programını öğretim üyeleri ve öğretmen adayları görüşleri doğrultusunda değerlendirdikleri çalışmalarında, öğretim üyeleri ve öğretmen adayları programdaki içerik kategorilerinin ağırlığına ilişkin bir değerlendirme de yapmışlardır. Öğretmen adaylarının programdaki alan ve alan eğitimi derslerinin ağırlığı hakkında görüş ayrılığı yaşadığ1 görülmektedir. Bir kısmı alan ve alan eğitiminin ağırlığının azaltılması yönünde, bir kısmı da değiştirilmemesi yönünde görüş bildirmişlerdir. Öğretim üyeleri ise alan ve alan eğitiminin ağırlı̆̆ının değiştirilmemesini istemektedir. Ayrıca öğretmen adayları meslek bilgisi ve genel kültür derslerinin ağırlığının artırılması gerektiğini düşünürken; öğretim üyeleri meslek bilgisi ve genel kültür derslerinin ağırlığının değiştirilmemesi görüşündedir. Ancak genel kültür derslerinin ağırlı̆̆ının değiştirilmesini düşünen akademisyen görüşleri de mevcuttur.

ITFB Dersine İlişkin Genel Görüş temasına bakıldığında, görüşmeye katılan akademisyenlerin hepsi daha önceki (2006) sınıf öğretmenliği programında yer alan Genel Fizik, Genel Kimya, Genel Biyoloji derslerine yeni programda (2018) yer verilmeyip, bu derslere adeta özet bir şekilde İTFB dersi adı altında verilmesini doğru bulmadıklarını ifade etmişlerdir. Akademisyenlere göre ITTFB dersi adeta fen bilimlerine giriş dersi niteliğindedir. Sadece bu dersi alan öğretmen adaylarının fen alanında donanımlı olamayacakları, dolayısıyla fen okur-yazar birey yetişemeyeceği düşüncesi hâkimdir. Akademisyenlerin en büyük tereddütlerinden biri de; üç saatlik bu derste hangi fen konusunun verilebileceğidir. Dolayısıyla bu derste verilecekler fizik, kimya ve biyoloji dersine ilişkin temel bilgilerden öteye gidilmeyecektir. Buna karşın alan yazındaki birçok çalışma akademisyenlerin bu görüşünü desteklememektedir. Şöyle ki alan yazın taraması yapıldığında, Genel Fizik, Genel Kimya ve Genel Biyoloji derslerinin öğretmenlere meslek hayatlarında önemli bir katkı sağlamadığı ve bu derslerin sınıf öğretmeni alanıyla ilgili olmadığ1 (Bağc1, 2014), bu derslerin gereksiz olduğu (Taşdemir, 1995), programdan çıkartılması gerektiği (Erbey, 2005), öğrenciler tarafından istenmediği (Türkoğlu, 2004), programda etkililiğinin düşük olduğu (Şahin ve Kartal, 2013), alan derslerinden en az yararlanılan dersler olduğu (Yavuzer, Dikici, Çalışkan ve Aytekin, 2006) şeklinde birçok çalışmaya rastlanılmıştır. Yurdakal (2018) değişen sınıf öğretmenliği lisans programı içeriğini incelediği çalışmasında, sınıf öğretmenlerinin ilkokul 1-4. sinıflardan sorumlu olduğuna vurgu yaparak ilkokul ders müfredatında yer almayan derslerin (Genel Fizik, Genel Kimya, Genel Biyoloji) lisans müfredatından kaldırılmasını olumlu bir gelişme olarak görmektedir. Alan yazındaki çalışmaların daha çok sınıf öğretmeni adayları ve sınıf öğretmenlerinin görüşleri alınarak yapıldığ1 görülmektedir. Bu derslere karşı sınıf öğretmeni adayları ve sınıf öğretmenlerinin olumsuz tutum sergilemelerinin en büyük sebebi bu derslerin sayısal ağırlıklı dersler olması dolayısıyla ders içeriklerinin ağır ve zor gelmesi olabilir. Ayrıca fen alan derslerini temelde iyi almamış olmaları bu derslere karşı olumsuz tutum sergilemelerine neden olabilmektedir. Belki de yeni sınıf öğretmenliği lisans programı hazırlanırken alan yazındaki bu çalışmalar dikkate alınarak Genel Fizik, Genel Kimya ve Genel Biyoloji 
dersleri kaldırılmış olabilir. Ancak fen alan derslerini almadan mezun olacak olan sınıf öğretmeni adaylarının ilkokuldaki fen bilimleri dersini anlatırken sahip oldukları bilginin yetip yetmeyeceği konusunda akademisyenler tereddüt içerisindedir.

İTFB Dersini Alan Öğretmen Adaylarının Fen Bilgisi Alan Yeterliliği temasına bakıldığında, akademisyenler sadece bu dersi alan öğretmen adaylarının fen alanında yeterince donanıma sahip olamayacağı, bu dersin fen bilgisine giriş niteliğinde olduğu, ilkokul öğrencilerinin fen alanındaki sorularına bile cevap veremeyecek öğretmenlerin yetişeceği, dolayısıyla bu durumun zaten düşük olan uluslararası sınavlardaki başarımızı daha da düşüreceği, Fen Bilimleri dersinin her alanın uzmanları tarafından ayrı ayrı verilmesi gerektiği düşüncesindedirler. Alan yazın taraması yapıldı̆̆ında, fen eğitiminde karşılaşılan en büyük problemlerden birinin ilköğretimde fen derslerini veren öğretmenlerin fen bilgisi konularında yeterli bilgi birikimine sahip olmadığıdır (İnce Aka, Yılmaz ve Karakaya, 2019).

Sınıf Öğretmeni Adaylarının 21. Yüzyıl Becerilerine Sahip Öğrenciler Yetiştirme Durumu temasına bakıldığında, akademisyenler sadece bu dersi alan öğretmen adaylarının yeterli fen donanıma sahip olamayacaklarını, öğretmenlerin öğrencilerine sadece sahip oldukları bilgiyi aktaracağı, dolayısıyla ustası yetersiz çıraklar yetişeceği şeklinde görüşler bildirmişlerdir. Okumuş ve Doymuş (2018)'a göre ders içeriklerinin birleştirilerek tek bir ders altında verilmesi konularda ayrıntıya inilmesini engellemektedir. Hâlbuki fen bilgisi dersi içinde yer alan fizik, kimya ve biyoloji dersleri birçok soyut kavramı içerir. Bu soyut kavramlar yeterince somutlaştırılmazsa öğrencilerde kavramları anlamama, yanlış anlama ve kavram yanılgısı gibi çeşitli problemler ortaya çıkar.

ITFB Dersinin İçeriğine Eklenmesi Gereken Konu Başlıkları temasına bakıldı̆̆ında, akademisyenler genel olarak bu derse başka konuların eklenmesinin sorunları (fen alan derslerinin kaldırılması, ilkokulda temel fen bilimleri dersinin süresi vb.) çözemeyeceği düşüncesindedirler. Ayrıca akademisyenlere göre bu dersin kim tarafından (fen bilgisi eğitimcisi mi? yoksa sınıf eğitimcisi mi?) verileceği de ayrı bir tartışma konusudur. Ayrıca bu dersin içeriğine ilkokul fen müfredatındaki konuların, temel süreç becerileri ve biyoloji konularının artırılarak eklenmesi yönünde görüş bildiren akademisyenler de vardir.

$\mathrm{Bu}$ araştırmanın sonuçları doğrultusunda şu önerilere yer verilebilir:

1. Yeni sınıf öğretmenliği lisans programı Bologna süreci ile uyumlu ve genellikle olumlu yönleri ön planda olan bir düzenleme görüntüsü verse de, fen alan derslerinin kaldırılması akademisyen görüşlerine göre programın tekrar gözden geçirilmesi gerektiği izlenimi vermektedir.

2. Lisans programları güncellenirken sadece Bologna süreci gibi uluslararası dönütler değil, aynı zamanda öğretmenlerin ve öğretmen adaylarının istek ve ihtiyaçları da dikkate alınmalıdır.

3. Lisans programları güncellenirken sadece öğretmen ve öğretmen adaylarının görüşleri değil, bu programın uygulayıcıları olan akademisyenlerin de görüşleri alınmalıdır.

4. Bu çalışma sadece Fırat ve İnönü üniversiteleri ile sınırlıdır. Bu çalışmanın kapsamı artırılarak yeni programla mezun olacak sınıf öğretmeni adaylarının fen donanımlık düzeyi detaylı bir şekilde araştırılmalıdır. 
5. Sınıf öğretmeni ve sınıf öğretmeni adayları tarafından ağır, detaylı ve zor olarak görülen Genel Fizik, Genel Kimya ve Genel Biyoloji derslerinin içeriği sadeleştirilmeli ve içeriği hazırlanırken ilkokul fen müfredatı dikkate alınarak ayrı ayrı verilmek suretiyle programa tekrar dâhil edilmelidir.

6. Yeni ve eski sınıf öğretmenliği lisans programını alarak mezun olacak olan öğrencilerin fen donanımlık düzeyleri geliştirilen başarı testleriyle karşılaştırılabilir. Elde edilen dönütler sonucunda programda yeni güncellemelere gidilebilir.

\section{Kaynakça}

Atanur Başkan, G., Aydın, A. ve Madden, T. (2006). Türkiye'deki öğretmen yetiştirme sistemine karşılaştırmalı bir bakış. Çukurova Üniversitesi Sosyal Bilimler Enstitüsü Dergisi, 15(1), 35-42.

Bağc1, E. (2014). Ĕ̆̈itim fakültesi sınıföğretmenliği programının paydaş görüşlerine göre değerlendirilmesi. (Yayınlanmamış Yüksek lisans tezi). Kilis 7 Aralık Üniversitesi Sosyal Bilimler Enstitüsü, Kilis.

Creswell, J. W. (2007). Qualitative inquiry E research design: Choosing among five approaches (2. bask1). USA: Sage Publications.

Çoban, A. (1996). Eğitim fakülteleri ile eğitim yüksekokullarının programlar açısından bütünleştirilmesi. (Yayınlanmamış Doktora Tezi). Ankara Üniversitesi Sosyal Bilimler Enstitüsü, Ankara.

Çoban, A. (2011). Sınıf öğretmenliği lisans programının değerlendirilmesi. Dicle Üniversitesi Ziya Gökalp Eğitim Fakültesi Dergisi, 16, 28-45.

Dağtekin, A. ve Zorluoğlu, S. L. (2019). The opinions of academicians on the updated science education undergraduate program. SDU International Journal of Educational Studies, 6(1), 36-53. https://doi.org/10.33710/ sduijes.538114

Erbey, Y. (2005). Sinıf öğretmenliği programının öğretmen yetiştirmedeki yeterliliğ i (Elazĭ̆Malatya-Diyarbakır örneği). (Yayınlanmamış Yüksek Lisans Tezi). Fırat Üniversitesi Sosyal Bilimler Enstitüsü, Elazı̆̆.

Gerring, J. (2007). Case Study Research: Principles and Practices. New York: Cambridge University Press.

Hallam, S. (2009). An evaluation of the social and emotional aspects of learning (seal) programme: Promoting positive behaviour, effective learning and well-being in primary school children. Oxford Review of Education, 35(3), 322-323. https://doi.org/10.1080/03054980902934597

İnce Aka, E., Y1lmaz, M. ve Karakaya, M. (2019). 2018 Fen bilgisi öğretmenliği lisans programındaki biyoloji derslerinin öğretmen görüşlerine göre değerlendirilmesi. Ihlara Eğitim Araştırmalan Dergisi, 4(1), 133-143.

Kavak, Y., Aydın, A., ve Akbaba-Altun, S. (2007). Öğretmen yetiştirme ve eğitim fakülteleri (1982-2007). Ankara: Yükseköğretim Kurulu Yayınları.

Kavcar, C. (1982). Tarihe karışan bir öğretmen modeli: Yüksek öğretmen okulu. Ankara Üniversitesi Eğitim Bilimleri Fakültesi Dergisi, 1(15), 197-214. https:// doi.org/10.1501/Egifak_0000000829

Kennedy, M. M., Ahn, S., and Choi, J. (2008). The value added by teacher education. In M. Cochran-Smith, S. Feiman-Nemser, \& D. J. McIntyre (Eds)., Handbook of 
research on teacher education: Enduring questions in changing contexts (3rd ed.) (pp. 1247-1271). Mahwah, NJ: Lawrence Erlbaum.

Kılıç Özmen, Z. (2019). 2018 Sınıf öğretmenliği lisans programının değerlendirilmesi. Anadolu Journal of Educational Sciences International, 9(2), 521-548. https:// doi.org/10.18039/ajesi.577387

Lincoln, Y. S., and Guba, E. G. (1985). Naturalistic Inquiry. Beverly Hills, CA: Sage. https:/ / doi.org/10.1016/0147-1767(85)90062-8

Merriam, S. B. (2013). Nitel araştırma desen ve uygulama için bir rehber. (Çev. Ed., S. Turan). Ankara: Nobel Yayıncilik.

Miles, M. B., and Huberman, A. M. (1994). Qualitative data analysis: An expanded sourcebook (2nd ed.). Thousand Oaks, CA: Sage.

Okumuş, S. ve Doymuş, K. (2018). İyi bir eğitim ortamı için yedi ilkenin işbirlikli öğrenme ve modellerle birlikte uygulanmasının 6. sinıf öğrencilerinin fen başarısına etkisi. Bayburt Eğitim Fakültesi Dergisi, 13(25), 203-238.

Özcan, M. (2013). Okulda üniversite: Türkiye' de öğretmen eğitimini yeniden yapılandırmak için bir model önerisi. 19 Kasım 2019 tarihinde https://tusiad.org/tr/yayinlar/raporlar/item/7344-okulda-universiteturkiyede-ogretmen-egitimini-yeniden-yapilandirmak-icin-bir-model-onerisi adresinden erişildi.

Strauss, A. L. and Corbin, J. (1990). Basics of Qualitative Research: Grounded Theory Procedures and Techniques. Newbury Park: Sage.

Şahin, Ç. ve Kartal, O. Y. (2013). Sınıf öğretmeni adaylarının sınıf öğretmeni yetiştirme programı hakkındaki görüşleri. Uşak Üniversitesi Sosyal Bilimler Dergisi, 6(1), 164-190. https:// doi.org/10.12780/UUSBD143

Taş, İ. D., Kunduroğlu Akar, T. ve Kıroğlu, E. (2017). Sınıf öğretmenliği lisans programının öğretim üyeleri ve öğretmen adaylarının görüşleri doğrultusunda değerlendirilmesi. Yüksek Öğretim ve Bilim Dergisi, 7(3), 578592.

Taşdemir, M. (1995). İlkokul öğretmeni yetiştirme programının öğretim elemanı, öğretmen ve öğrenci görüşlerine göre değerlendirilmesi. (Yayınlanmamış Doktora Tezi). Hacettepe Üniversitesi Sosyal Bilimler Enstitüsü, Ankara.

Türkoğlu, S. (2004). Çukurova ve Mersin üniversitesi sını öğretmenliği programlarııın değerlendirilmesi. (Yayınlanmamış Yüksek Lisans Tezi). Çukurova Üniversitesi Sosyal Bilimler Enstitüsü, Adana.

Wengraf, T. (2001). Qualitative research interviewing: Biographic narrative and semi structured methods. Thousand Oaks, CA: Sage. https:/ / doi.org/10.4135/9781849209717

Yavuzer, Y., Dikici, A., Çalışkan, M. ve Aytekin, H. (2006). Sınıf öğretmenliği mezunlarının öğretmen yetiştirme programından yararlanma düzeylerine ilişkin görüşleri (Niğde üniversitesi örneği). Çukurova Üniversitesi Ĕ̆itim Fakültesi Dergisi, 3(32), 35-41.

Yıldırım, A. (2011). Öğretmen eğitiminde çatışma alanları ve yeniden yapılanma. Uluslararası Ĕ̆itim Programları ve Öğretim Çalışmaları Dergisi, 1(1), 1-17.

Yıldırım, A. ve Şimşek H. (2006). Sosyal Bilimlerde Nitel Araştırma Yöntemleri. Ankara: Seçkin Yayıncılık. 
Yıldırım, A. ve Şimşek H. (2008). Sosyal Bilimlerde Nitel Araştırma Yöntemleri (6. baskı). Ankara: Seçkin Yayıncılık.

Yıldırım, A. ve Şimşek, H. (2011). Sosyal Bilimlerde Nitel Araştırma Yöntemleri (8.baskı). Ankara: Seçkin Yayıncılık.

Yıldırım, A. ve Şimşek, H. (2016). Sosyal Bilimlerde Nitel Araştırma Yöntemleri (10.bask1). Ankara: Seçkin Yayıncılık.

Yin, R.K. (2014). Case Study Methods: Design and Methods (5. bask1). Thousand Oaks: Sage Publications.

YÖK (2006). Sını öğretmenliği lisans programı. 20 Kasım 2019 tarihinde http:/ / bbs.bim.gantep.edu.tr/(S(4gpgqgelz3rqx1clxhl30dye))/prog_navigat or.aspx?path=2_3 adresinden erişildi.

YÖK (2018). Sını öğretmenliği lisans programı, yeni öğretmen yetiştirme lisans programları. 20 Kasim 2019 tarihinde https:// www.yok.gov.tr/kurumsal/idari-birimler/egitim-ogretimdairesi/yeni-ogretmen-yetistirme-lisans-programlari adresinden erişildi.

Yurdakal, İ. H. (2018). Değişen sınıf öğretmenliği lisans program içeriğinin incelenmesi. Ulakbilge, 6(29), 1483-1499. https:// doi.org/10.7816/ulakbilge06-29-10

Yüksel, S. (2015). Öğretmen yetiştirme politikalarında dönüşüm: 21. yy. öğretmenini yetiştirme. Türkiye Özel Okullar Birliği Dergisi, 32, 23-28.

\section{Summary}

\section{Introduction}

Following the transfer of the function of educating teachers to universities in 1982, revisions were made in the teacher education bachelor programs in 1997, 2006 and 2009, whereas the final revision on the programs was made in 2018. The new program was applied only on 1st-year undergraduate students during the 2018-2019 academic year. The other classes are continuing the program they started the undergraduate program with (Kılıç Özmen, 2019). Primary school teaching is among the primary areas of teaching that underwent the most of revisions throughout the historical process due to its complex structure (Çoban, 2011). The changes in all the courses included in the new undergraduate degree program for primary school teaching and especially those in the science courses make up the most striking aspect of the program. Specialized field courses such as General Physics, General Chemistry and General Biology have been removed from the program. It was aimed with the works carried out in this context to put forth the opinions of the academics as well as their assessments on Elementary Science Course in Primary School (ESCPS).

\section{Method}

This study is a qualitative research. The study group was comprised of 10 academic staff working at Frrat University and Inonu University during the spring semester of the 2018-2019 academic year who accepted to take part in the interviews. Criterion sampling from among the purposive sampling methods was used for determining the participants. Interview method from among the qualitative data collection methods 
was used to collect the data. For this purpose, the researchers prepared a semistructured interview form. The content analysis method was used for data analysis.

\section{Results and Discussion}

It can be observed when the results put forth by the findings obtained from the study data were examined that the faculty members generally did not consider the program distribution as appropriate in the theme of General Opinions on the Revised New Teaching Undergraduate Program. It can be observed when the opinions of academics are considered that the participants focused especially on the problems that may emerge when the subject courses in the programs are reduced. Based on the findings of numerous studies in the literature, there is a debate on whether subject matter knowledge or the professional teaching knowledge should be predominant in the process of educating teachers. According to Yildırım (2011), the answer to this question is actually related to the meaning ascribed to teachers. While according to subject area understanding, importance should be given to subject area education in order to educate high-quality teachers, qualified teachers can be described according to the understanding of the professional teaching knowledge as individuals who are well versed in using the proper methods and techniques during the education process.

When the theme of General Opinions on ESCPS Course is examined, all of the academics who took part in the interviews stated that they do not consider it right that the General Physics, General Chemistry and General Biology courses have not been included in the revised program (2008) which were present in the previous (2006) primary school teaching program and to include these courses as short summaries under the title of ESCPS course. According to the academics, the ESCPS course has the characteristics of an introductory science course. In addition, the answer to the question of which science topic can be taught during this three-hour course is one of the major reasons for the hesitancy of the teachers. Thus, the only fundamental knowledge of physics, chemistry and biology can be taught during this course. It was observed as a result of the review of literature that there are many studies in which it has been put forth that General Physics, General Chemistry and General Biology courses have not made significant contributions to the teachers during their professional lives (Bağc1, 2014), these courses are unnecessary (Taşdemir, 1998), they should be removed from the program (Erbey, 2005), the students do not want them (Türkoğlu, 2004), their effectiveness is low in the program (Şahin and Kartal) and they are the courses with the least benefit for teachers (Yavuzer, Dikici, Çalışkan and Aytekin, 2006). It is observed that these studies in literature have been carried out mostly by taking the opinions of primary school teacher candidates and primary school teachers. The major reason why primary school teacher candidates and primary school teachers have displayed a negative attitude towards these courses can be the fact that these courses are mostly numerical and thus they have difficulty in acquiring the course content.

When the theme of Science Competence Status of Teacher Candidates Who Have Taken the ESCPS Course is considered, it is observed that the academics think that the teacher candidates who take only this course will not have sufficient competence and that there may even be teachers who will not be able to respond to the questions of primary school students on the subjects of science. It was observed as a result of the literature review that one of the most important problems encountered in science 
education is lack of sufficient knowledge of science teachers at primary schools (İnce Aka, Yilmaz and Karakaya, 2019).

It can be observed when the theme of The Status of Classroom Teacher Candidates to Raise Students with $21^{\text {st }}$ Century Skills that the academics are of the opinion that the teacher candidates who take only this course will not have sufficient scientific knowledge, that they will pass on to their students only the knowledge they have thereby leading to educating apprentices with incompetent masters. According to Okumuş and Doymuş (2018), combining the course content in a single course prevents the detailing of the subjects. However, the courses of physics, chemistry and biology that are parts of the science course include many abstract concepts. Various problems such as failure to understand the concepts, misunderstanding and misconception will arise if these abstract concepts are not made sufficiently tangible.

It was observed when the theme of Subject Headlines to be Included in the ESCPS Course was examined that the academics generally think that including new subjects to this course will not solve the problems (removing the science area courses, duration of the ESCPS course etc.).

\section{Pedagogical Implications}

Pre-school teachers and primary school teachers are the first to shape the students as well as the professions in the community. Hence the importance of educating these teachers is increasing by day by. Moreover, academics undoubtedly play the most important role in ensuring that the undergraduate programs are effective and efficient. Revisions made in the content of all courses in the undergraduate program of the new primary school teaching bachelor's degree program and especially the revisions made in the content of the science course make up the most striking aspect of the program. Opinions of academics with regard to the content of the courses included in the new undergraduate program may provide important findings with regard to making the necessary revisions to make these programs more effective. In addition, the fact that there is a small number of studies evaluating these programs and the course content further increases the importance of the present study.

\section{Araştırmanın Etik İzinleri}

Yapılan bu çalışmada "Yükseköğretim Kurumları Bilimsel Araştırma ve Yayın Etiği Yönergesi" kapsamında uyulması belirtilen tüm kurallara uyulmuştur. Yönergenin ikinci bölümü olan "Bilimsel Araştırma ve Yayın Etiğine Aykırı Eylemler" başlı̆̆ı altında belirtilen eylemlerden hiçbiri gerçekleştirilmemiştir.

Etik kurul izin bilgileri

Etik değerlendirmeyi yapan kurul ad1 = Gaziantep Üniversitesi Sosyal ve Beşeri Bilimler Etik Kurulu

Etik değerlendirme kararının tarihi= 13.08.2020

Etik değerlendirme belgesi sayı numarası $=37318$

\section{Authors' Biodata/ Yazar Bilgileri}

Sümeyye AYDIN GÜRLER Gaziantep Üniversitesi Nizip Eğitim Fakültesi Matematik ve Fen Bilimleri Eğitimi Bölümü'nde Dr. Öğretim Üyesi olarak görev yapmaktadır. 
Sümeyye Aydın Gürler works as an Assistant Professor at Gaziantep University, Nizip Faculty of Education, Department of Mathematics and Science Education.

Oktay BAYKARA Furat Üniversitesi Eğitim Fakültesi Matematik ve Fen Bilimleri Eğitimi Bölümü'nde Profesör Doktor olarak görev yapmaktadır.

Oktay Baykara works as a Professor at Firat University, Faculty of Education, Department of Mathematics and Science Education. 